\title{
Trees as a solar control measure for southern-oriented street frontages. Analysis of a selected street model for a humid continental climate
}

\author{
Katarzyna Zielonko-Jung ${ }^{1}$ • Justyna Janiak ${ }^{2}$ iD
}

Accepted: 10 May 2021 / Published online: 9 June 2021

(C) The Author(s) 2021

\begin{abstract}
The present study is aimed at the analysis of possibilities for shading southern frontage of street oriented along the E-W axis by the single row of trees, parallel to the southern elevations. The effectiveness of solar control shading was tested depending on the geometric relationships between trees and buildings. Numerical simulation analyses were conducted in Rhinoceros ${ }^{\circledR}$ program for the street located in humid continental climate in city Płock, Poland (52 $32^{\prime} 50$ ' $\left.\mathrm{N} 19^{\circ} 42^{\prime} 00^{\prime \prime} \mathrm{E}\right)$, for the day of the highest degree of total solar radiation in the year i.e. June 7th, during hours: 8.00a.m - 5.00 p.m. The analysis has proved that a row of $20-25$ year old Sycamore Maple 'Rotterdam' in the street $30 \mathrm{~m}$ wide and $18 \mathrm{~m}$ high $(\mathrm{H} / \mathrm{W}=0.6)$, can provide solar protection for the southern frontage, especially when trees are located no more than $4 \mathrm{~m}$ away. Location of greenery within the range of 4 to $5 \mathrm{~m}$ from the buildings leads to a radical reduction in the possibility of shading the wall surfaces (at $5 \mathrm{~m}$ to $0 \%$ ). Over $90 \%$ of the shading area of the ground floor façade walls was found when trees were within the distance 2 and $3 \mathrm{~m}$ away from the building.
\end{abstract}

Keywords Trees $\cdot$ Shading $\cdot$ Solar radiation $\cdot$ Street canyon $\cdot$ Sustainable planning

\section{Introduction}

Properly located trees provide effective solar protection against direct insolation both, for building developments and the surrounding area (for example, Heisler 1986; Shashua-Bar and Hoffman 2000; Abdel-Aziz 2014). In the era of progressing urbanization and the climate change, benefits that stem from the shadowing role of greenery are considerable, especially for residents of 21-first century cities, who tend to be exposed to the urban heat island phenomenon. An appropriate degree of vegetation used as urban area shading element improves the thermal comfort of city users (Kong et al. 2017; Shashua-Bar and Hoffman 2000; Mayer and Ali-Toudert 2005; Bowler et al. 2010) and may exert a significant impact on reduction of electricity demand allocated for air conditioning of building interiors on hot summer days (Donovan and

Justyna Janiak

justyna.janiak@pw.edu.pl

1 Faculty of Architecture, Gdańsk University of Technology, Gdańsk, Poland

2 Institute of Civil Engineering, Faculty of Civil Engineering, Mechanics and Petrochemistry, Warsaw University of Technology, Łukasiewicza Street 17, 09-400 Płock, Poland
Butry 2009). At the same time, shading elements of greenery serve a number of other, equally important functions, including: ecological, psychological or social (Czerwieniec and Lewińska 2000; Navarrete-Hernandez and Laffan 2019; Huang et al. 2020). This fact accounts for their wide application in city spaces in a way that makes it possible to combine a number of various advantages through a thoughtful location of plants and through their proper choice.

In the research literature a large group of works can be found that are devoted to the shadowing role of trees located within free-standing buildings. These papers have been authored by, among other researchers, McPherson and Simpson (2003); Akbari et al. (1997); Laband and Sophocleus (2009). Studies conducted so far provide plentiful information and data on the impact of green elements applied as solar protection measures on individual residential buildings, including impacts in terms of electricity consumption required for air conditioning operating in the building developments shaded by trees (McPherson and Simpson 2003), on facade surface temperature (McPherson and Heisler 1988; Simá et al. 2015) or on the degree of shortwave radiation reduction (Abdel-Aziz 2014). However, few publications by, for instance, Shashua-Bar and Hoffman (2000), Shashua-Bar et al. (2009), or Mayer and Ali-Toudert (2005) refer to high-rise greenery located in urban interiors, such as city streets or squares. 
In the case of research concerning trees growing in highly urbanized areas, the focus is mainly placed on the impact of greenery on the microclimate found in a given place and, in particular, the air temperature. However, a deficient amount of research work is visible when considering the possibility to apply trees in order to shade street frontages exposed to intense insolation, especially in dense urban building developments. Spatial conditions, together with various restrictions resulting from factors, such as area availability, or from the existing technical infrastructure raise questions on the possible ways and methods to apply high-rise greenery to protect buildings against direct solar radiation. It seems proper to analyse the situations, in which trees may be treated as an alternative to solar control systems mounted on glazing in order to protect the interiors from overheating.

The present study seeks its main goal in analysing the possibility of using deciduous trees as solar protection measure for southern facades in a compact street building development layout. The research made it possible to assess the potential of high-rise greenery as elements of solar protection in the street space on the E-W axis, with shading conditions created by the geometry of buildings of medium height i.e., over $12 \mathrm{~m}$ to $25 \mathrm{~m}$ in height. The analyses were conducted for a $30-\mathrm{m}-$ wide street model, lined with terraced buildings, $18 \mathrm{~m}$ in height (6 storeys) that form compact frontages. The building height to street width parameter, $\mathrm{H} / \mathrm{W}$, which is widely applied in researches related to spaces known as street canyons (a simplified vertical street profile; the term commonly applied in the context of urban climate research as the basic structural unit with which to describe urban space) (Arnfield 1990), amounts to the value of 0.6 in case of the considered model. The adopted $\mathrm{H} / \mathrm{W}$ ratio indicator defines the geometry of building developments, which according to Oke (1988) is likely to exert a positive impact on the area microclimate in terms of sun availability, ventilation or shading.

In order to verify the possibility of applying trees to protect southern facades from excessive insolation, a simulation was conducted for a selected summer day, characterised by the highest degree of solar radiation intensity, i.e. on June 7 . The assessment concerning chances to benefit from deciduous trees as protection measure against excessive insolation of the southern facades was based on the analysis of the wall area shaded by greenery, expressed in $\mathrm{m}^{2}$ and in percent (as a share in the entire area considered), as well as in terms of the shading duration in time.

\section{Materials and methods}

Numerical simulation analyses were conducted in the Rhinoceros ${ }^{\circledR}$ programme (Robert McNeel \& Associates), version 6 (widely available to urban designers), with the use of the Grasshopper ${ }^{\circledR}$ algorithm editor, integrated with it, and with the parametric environmental plugin Ladybug Tools. In addition, the Sunlight Hours Analysis tool was used, which allows to determine the number of hours in which the tested object receives direct sunlight in a given time. The algorithm developed in the computer program offers a chance to measure the shaded area in $\mathrm{m}^{2}$ on both vertical and horizontal planes.

\section{Street model}

The tested model is a representation of a 30-m wide street of symmetrical profile. It consists of a simplified building development formed into compact, parallel, 40-m long, rectangular rows with a row of trees located inside (Fig. 1).

The model was placed along the $\mathrm{E}-\mathrm{W}$ axis direction, whereas the analysis concerned the southern façade. The southern façade is precisely the case in which, owing to the intense insolation it receives in the summer, it is advisable to mount external shading systems to cover glazing to protect the interior from heat excess, as well as from excessive light, thus to avoid an increase in energy expenditure related to air conditioning required. Therefore, it seems accurate to search for the ways in which trees located along the street may be applied

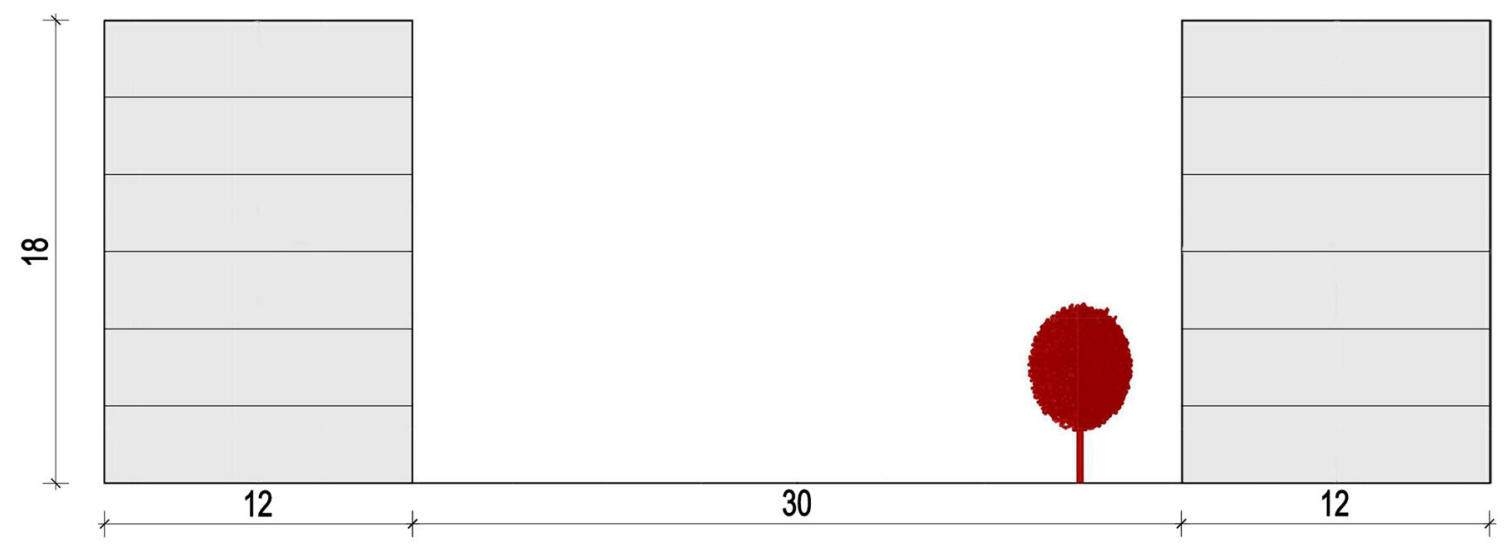

Fig. 1 Investigated street canyon including trees [m] 
Table 1 The characteristics of the selected parameters concerning the tree chosen for the research purposes. Data based on online maple catalog (2019), online plant catalog (2010) as well as on Seneta and Dolatowski (2012)

\begin{tabular}{ll}
\hline Characteristics & Sycamore Maple 'Rotterdam' \\
\hline $\begin{array}{l}\text { Max. height in urban conditions } \\
{[\mathrm{m}]}\end{array}$ & $15-20 \mathrm{~m}$ \\
$\begin{array}{l}\text { Max. width of the tree crown }[\mathrm{m}] \\
\text { Habit }\end{array}$ & $6-10 \mathrm{~m}$ \\
Growth pace & dense crown, obovate, pyramidal shape \\
Soil requirements & small soil requirements \\
Tolerance to drought & high \\
Tolerance to soil pH & high \\
Tolerance to air pollution & high \\
Resistance to soil salinisation & yes \\
Positioning- light requirements & Sunny or partial shade exposure \\
Care & No particular requirements \\
To be used & e.g. to be planted around streets, parking lots and as housing estate \\
& greenery \\
\hline
\end{tabular}

as solar protection measure. The simulation was conducted for a street located in the humid continental climate zone on the example of the city of Płock (52 ${ }^{\circ} 32^{\prime} 50$ “'N $19^{\circ} 42^{\prime} 00^{\prime}$ ” E; 58$105 \mathrm{~m}$ a.s.1.). The selected city is located in the centre of Poland where total solar radiation is one of the highest in this country (Błażejczyk et al. 2015).

\section{Tree model}

In order to determine the extent of shading shed on the façade surface by deciduous trees, it was vital to properly define the high-rise greenery model. In the existing simulation studies involving the effect of trees, various ways for modelling plant elements that constitute solar protection measures can be found. In the study by Hes et al. (2011) the tree crown was presented as two circular planes, perforated in $50 \%$, intersecting in three dimensions at right angle. In turn, in the publication by Thayer et al. (1985), a row of high-rise greenery was simplified and represented by a cylinder, whose width

Table 2 Main parameters of the model tree built for the needs of computer simulation

\begin{tabular}{ll}
\hline Characteristics & Sycamore Maple 'Rotterdam' \\
\hline Trunk circumfrence & $0,44 \mathrm{~m}$ \\
Tree crown width & $4 \mathrm{~m}$ \\
Tree crown height & $5 \mathrm{~m}$ \\
Tree crown shape & oval \\
Height from the tree crown base & $2 \mathrm{~m}$ \\
Total height of the tree & $7 \mathrm{~m}$ \\
LAI & 6 \\
\hline
\end{tabular}

equals the spread of a mature tree. Thereafter, the cylinder was bestowed with the appropriate value of shading coefficient.

In the present study, a much more accurate model was adopted, though also with unavoidable simplifications. However, the most crucial research parameters were maintained, namely tree height, crown spread and shape, as well as foliage density, expressed by LAI index (Leaf Area Index). The tree crown was modelled to resemble a set of randomly oriented and placed planes that represent the leaves, all of which form a flattened sphere. The leaf models were given a simplified circle shape with an area equal to the leaf area. A specific tree species was selected for this study as a pattern for the geometry of the model. It is Sycamore Maple the cultivar 'Rotterdam', a tree commonly found in European cities. The tree is characterized by high resistance to conditions

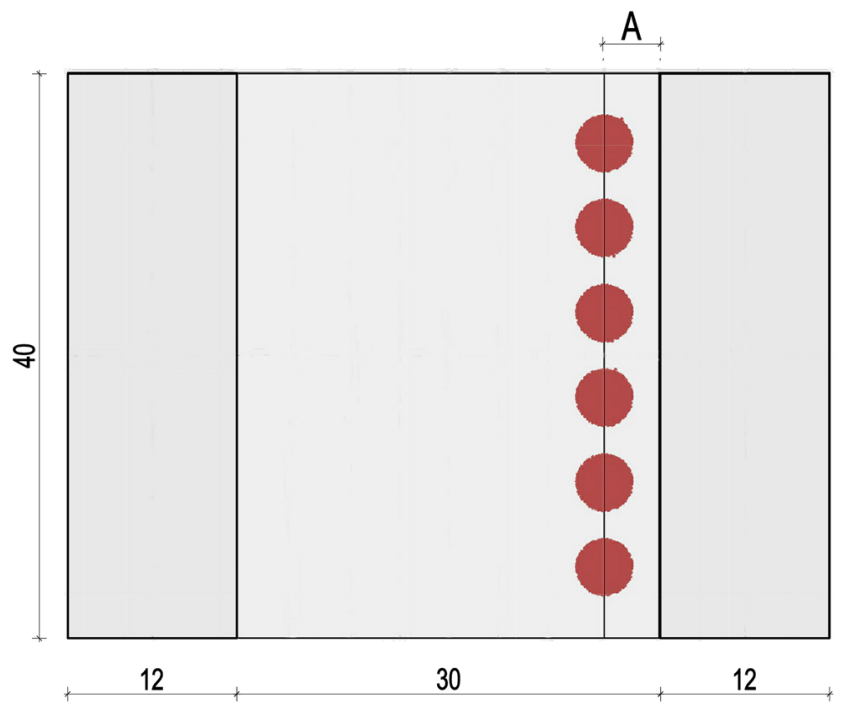

Fig. 2 Location of the tree row in front of the southern façade, $18 \mathrm{~m}$ in height, in a 30-m wide street. For different variants, the distances between the greenery row and buildings (A) equal 2, 3, 4 and $6 \mathrm{~m}$ 
observable in a highly urbanized environment and is recommended for planting roads and streets. Its parameters, significant from the research point of view, are presented in Table 1.

The model, constructed for the needs of the study, represents a 20-25 year old representative of this species, whose circumference equals $0.44 \mathrm{~m}$ (other parameters are presented in Table 2). 20-25 year old Sycamore Maples were selected for the study to analyse the possibilities of shading by trees that have not reached maturity. While fully formed trees have the greatest shading potential, the problem is their long growth period. Therefore, it was decided to analyse the trees at the age when immediately after planting, they can serve as elements protecting the buildings and the area from direct sun radiation.

\section{Model representing the location of trees in relation to buildings}

In the simulation analyses, it was assumed that the trees, modelled in accordance with the parameters described above, form a row parallel to the street axis, located in vicinity of the southern frontage (Fig. 2).

The distance between the tree trunks in the row equals $6 \mathrm{~m}$, which should leave space for further development of tree crowns provided that trees were growing in natural conditions. Over time, the trees would develop into a dense, compact form of green avenue. In order to investigate the influence of geometrical relations between greenery and street frontage on the sun protection of buildings, the simulation was performed for 4 diverse distances of the tree row from the façade exposed to insolation, that is 2, 3, 4 and 6-m distance. Such distance values were selected following the analysis on the possible

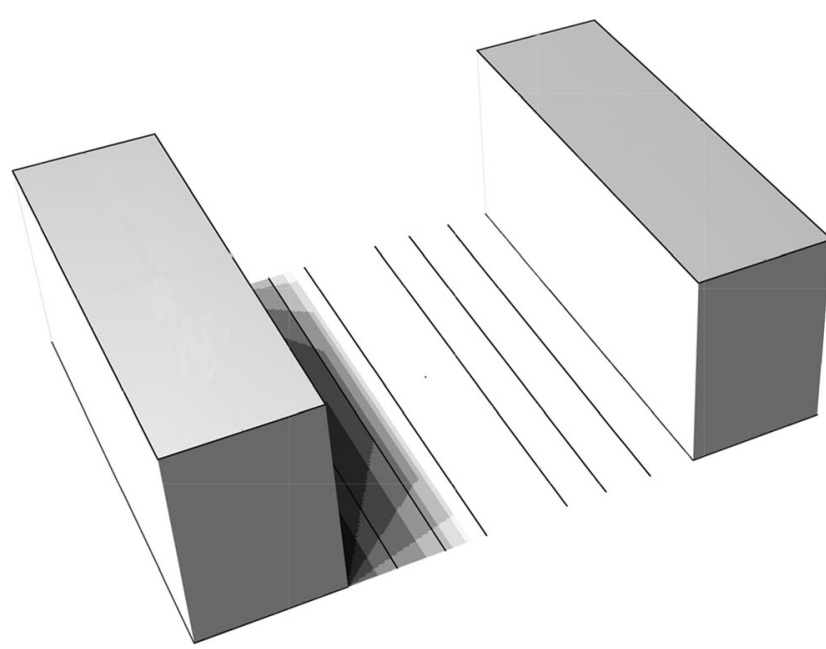

Fig. 3 Solar exposure of the street canyon, on the E-W axis, on June, the 7, between 8.00 a.m. to 5.00 p.m. (at selected location)
Table 3 The shading area for southern façade, with an area of $720 \mathrm{~m}^{2}$, by a row of trees set at various distances from the building development

\begin{tabular}{lllll}
\hline $\begin{array}{l}\text { Distance of trees } \\
\text { from the } \\
\text { buildings }\left[\mathrm{m}^{2}\right]\end{array}$ & $\begin{array}{l}\text { Minimum } \\
\text { shaded area } \\
{\left[\mathrm{m}^{2}\right]}\end{array}$ & $\begin{array}{l}\text { Maximum } \\
\text { shaded area } \\
{\left[\mathrm{m}^{2}\right]}\end{array}$ & $\begin{array}{l}\text { Total } \\
\text { shaded } \\
\text { area }\left[\mathrm{m}^{2}\right]\end{array}$ & $\begin{array}{l}\text { \% of total } \\
\text { facade } \\
\text { shaded area }\end{array}$ \\
\hline $2 \mathrm{~m}$ & 96.84 & 121.77 & 184.12 & $25.57 \%$ \\
$3 \mathrm{~m}$ & 18.57 & 58.53 & 119.56 & $16.61 \%$ \\
$4 \mathrm{~m}$ & 4.28 & 20.94 & 52.72 & $7.18 \%$ \\
$5 \mathrm{~m}$ & 0 & 0 & 0 & 0 \\
\hline
\end{tabular}

location of trees in case of a vehicle traffic-adapted street. The data applied for the research concerned collective roads and the main one-lane street (Borowski and Pstragowska 2009). Although the selected location of the row close to the building, i.e., $2 \mathrm{~m}$ away, may in fact be associated with some problems, together with other considered variants it allows to fully analyze the potential of greenery as a shading element. The adopted solar exposure conditions correspond to those prevailing during the day when the highest degree of direct solar radiation intensity is observed on the horizontal surface, for the town of Płock, namely for June, the 7. (data according to the Polish Ministry of Investment and Development regarding typical meteorological years and statistical climate data for energy-related calculations in case of buildings for a selected location - Płock Trzepowo). The shading area was measured once, between 8.00 a.m. to 5 p.m. The measurement was also divided into hourly intervals (8.00-9.00 a.m., etc.). Limiting the simulation to one day allowed for an accurate analysis of insolation and shaded surfaces in the street space.

\section{Results}

On the examined day of June, the 7, the south frontage is subjected to full exposition to solar radiation throughout the entire study period, i.e., for $9 \mathrm{~h}$. This situation results from the fact that the opposite building development is only effective in shading horizontal surfaces in the street division lines (Fig. 3).

Table 4 The shading area for ground floor southern façade, with an area of $120 \mathrm{~m}^{2}$, by a row of trees situated at various distances from the building development

\begin{tabular}{lllll}
\hline $\begin{array}{l}\text { stance of trees } \\
\text { from the } \\
\text { buildings }\left[\mathrm{m}^{2}\right]\end{array}$ & $\begin{array}{l}\text { Minimum } \\
\text { shaded area } \\
{\left[\mathrm{m}^{2}\right]}\end{array}$ & $\begin{array}{l}\text { Maximum } \\
\text { shaded area } \\
{\left[\mathrm{m}^{2}\right]}\end{array}$ & $\begin{array}{l}\text { Total } \\
\text { shaded } \\
\text { area }[\mathrm{m}\end{array}$ & $\begin{array}{l}\text { \% of total } \\
\text { facade } \\
\text { shaded area }\end{array}$ \\
\hline $2 \mathrm{~m}$ & 67.30 & 88.92 & 119.92 & $99.93 \%$ \\
$3 \mathrm{~m}$ & 18.57 & 56.48 & 113.13 & $94.28 \%$ \\
$4 \mathrm{~m}$ & 4.28 & 20.94 & 51.74 & $43.11 \%$ \\
$5 \mathrm{~m}$ & 0 & 0 & 0 & 0 \\
\hline
\end{tabular}


At the same time, only $34.00 \%$ of the street area surface is shaded against direct solar radiation, whereas only $4.31 \%$ of that area is protected throughout the simulation. Insolation conditions that prevail in the analysed street canyon provide a rationale for the use of solar control shading on the southern façade glazing. Moreover, it seems advisable to shade the street canyon floor.

In Table 3, the southern facade shading area by a row of trees is presented, depending on its distance from the building development line. As the research has shown, trees (in the conditions adopted for analysis) fail to provide any protection against direct sunrays, in case the row of trees is located $5 \mathrm{~m}$ away from the object it is supposed to shade. However, for the closest distance studied, namely $2 \mathrm{~m}$ away from the building development, trees are capable of shading up to $25.57 \%$ of the façade area throughout the research. At the same time, the largest area shaded (6.34\%) receives shade for 5 to $6 \mathrm{~h}$. Maximum shading does not exceed $17 \%$ of the façade surface, whereas the minimum shading equals $13.45 \%$. Increasing the distance of plant shading elements from the building by $2 \mathrm{~m}$ (from 2 to $4 \mathrm{~m}$ away) decreases the total area protected from insolation by more than $18 \%$ and reduces the maximum possible shade by almost 6 times. In the latter case, a decrease in the shading duration to $1 \mathrm{~h}$ was noticed for the largest part of the facade surface $(3.18 \%)$ in the period between 8.00 a.m. and 5.00 p.m. For the studied layout of medium-high buildings $(\mathrm{H}=18 \mathrm{~m})$ that form a dense street line, 20- to 25-yearold trees, of $7 \mathrm{~m}$ in height, regardless of their location, provide sufficient solar protection measure only for a part of the southern façade surface (for $25.57 \%$ at most).

According to the data presented in Table 4, trees can provide an effective solar control measure for the ground floor façades, in case they are located at a distance of 2 to $3 \mathrm{~m}$ away from the building. Trees located $2 \mathrm{~m}$ away from the street frontage are only capable of shading the surface of between $56 \%$ to $74 \%$ of the walls to a height of $3 \mathrm{~m}$ for the whole simulation period. This, together, accounts for $99.93 \%$ of the ground floor facade surface receiving protection from direct solar radiation. On the other hand, the location of trees at $3 \mathrm{~m}$ away from the building development yields similar results. In this case, $94.28 \%$ of the ground floor façade, in total, is shaded by trees if they are located at a distance of $3 \mathrm{~m}$, with a maximum shade indicator not exceeding $47.07 \%$ of the entire area. While changing the location of the trees from 2 to $3 \mathrm{~m}$ may not cause significant differences in the total shading area of the ground floor, a significant drop to $43 \%$ was recorded when the trees were located at a distance of $4 \mathrm{~m}$ away.

Comparing the data presented in Tables 3 and 4 , it can be stated that trees planted $4 \mathrm{~m}$ away from the facade fail to provide solar protection measure for the part of the building above the ground floor level, whose height was assumed in the study to equal $3 \mathrm{~m}$. However, trees located at a distance of $2 \mathrm{~m}$ from the building may shade up to $54 \%$ of the first floor façade surface (within the range from $20.98 \mathrm{~m}^{2}$ to $33.85 \mathrm{~m}^{2}$ ) throughout the simulation period (Fig. 4). Moving the row of trees one meter further causes a significant, over tenfold, decrease in the range of wall area receiving shade at the level of the first floor (max. 2.52\%) (Fig. 5). Additionally, the façade of the storey above the ground floor level will be shaded for 4 out of $9 \mathrm{~h}$ of total solar exposure. This means that only a very close location of the trees (such as at the distance of $2 \mathrm{~m}$ ) along the southern frontage of the building development is capable of providing at least partial protection against insolation for the first floor façade.

In all the cases under consideration, in which high greenery is applied to provide solar protection, the façades are, to a varying extent, covered with protection for at least $66 \%$ of the time between 8.00 a.m. and 5 p.m. (Fig. 6). Trees are an
Fig. 4 The area of ground floor and first floor southern facade shaded by trees planted at a distance of $2 \mathrm{~m}$ from the building on July 7 th, between 8 a.m. to 5 p.m.

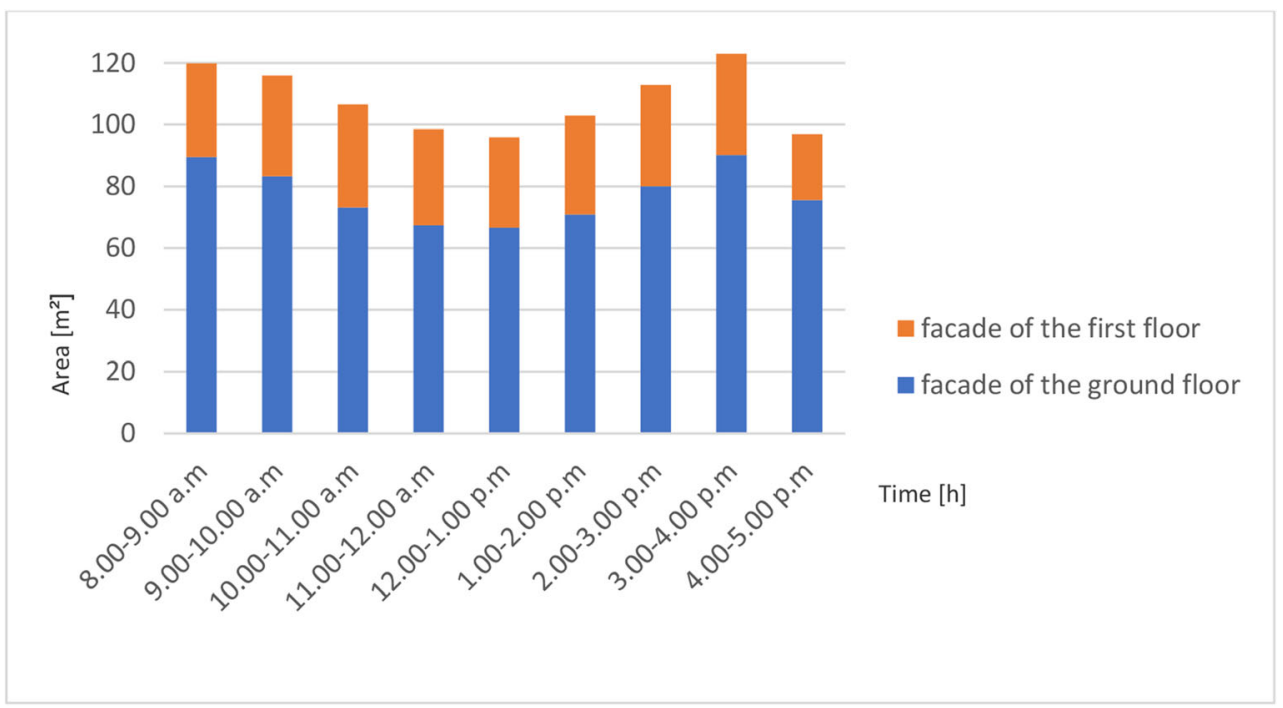


Fig. 5 The area of ground floor and first floor southern facade shaded by trees planted at a distance of $3 \mathrm{~m}$ from the building on July 7 th, between 8 a.m. to 5 p.m.

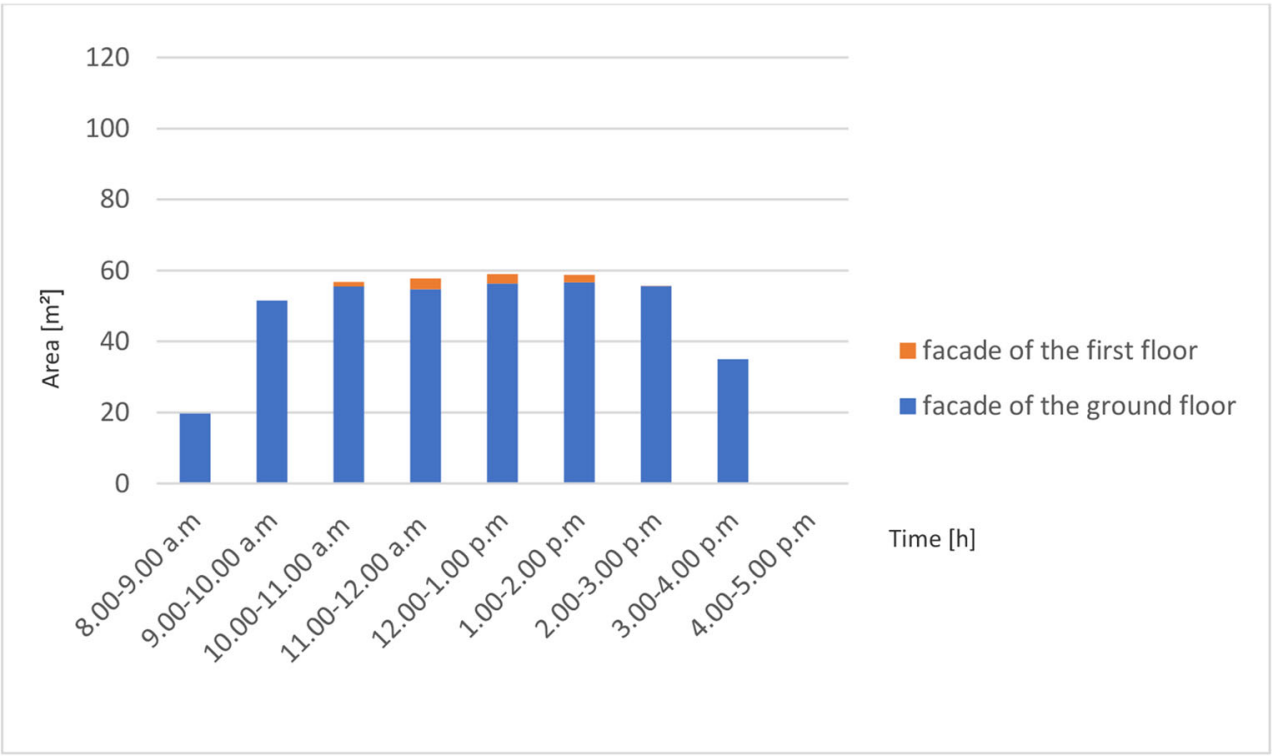

effective measure in protecting façades against direct solar exposure, provided they are placed at a very short distance to the walls of the building development.

Trees at a distance of $2 \mathrm{~m}$ provide shading for the facade surface throughout the entire simulation period, that is for $9 \mathrm{~h}$. However, if the greenery is planted $1 \mathrm{~m}$ further from buildings, the shading time shortens by $1 \mathrm{~h}$, and with a distance of $2 \mathrm{~m}$ further (up to $4 \mathrm{~m}$ away from buildings), the shading time is $1 / 3$ shorter than the span of solar exposure. When planting greenery as shading elements 2 and $3 \mathrm{~m}$ from the outer walls of the building development, also ground floor glazing receives protection against insolation within the hours marked with the highest total intensity of solar radiation (over $400 \mathrm{~W} / \mathrm{m}^{2}$ ), i.e. from 8.00 a.m. to
1 p.m. Likewise, in the case of trees growing at a distance of $4 \mathrm{~m}$ away from the building development, much less solar protection is provided (together such trees shade about $43 \%$ of the ground floor façade), whereas the protection lasts since 9.00 a.m. onwards. In turn, the period of maximum shading of the façade surface varies depending on the location of the trees. For plants at a distance of $2 \mathrm{~m}$ away from the sheltered walls, the maximum shade is received at 3-4 p.m., with the trees at $3 \mathrm{~m}$ away from buildings at $1-2$ p.m., whereas the earliest shading time, from 11 to 12 a.m. is observable for a distance of $4 \mathrm{~m}$ away from buildings. The largest differences in terms of surface shading between the variants with different tree locations were recorded between 8 a.m.-10 a.m. and 2 p.m.-5 p.m. (Fig. 7).
Fig. 6 Shading time for the southern facade by trees set at different distances from the building developments, recorded between 8.00 a.m. to 5 p.m. (on July, 7th)

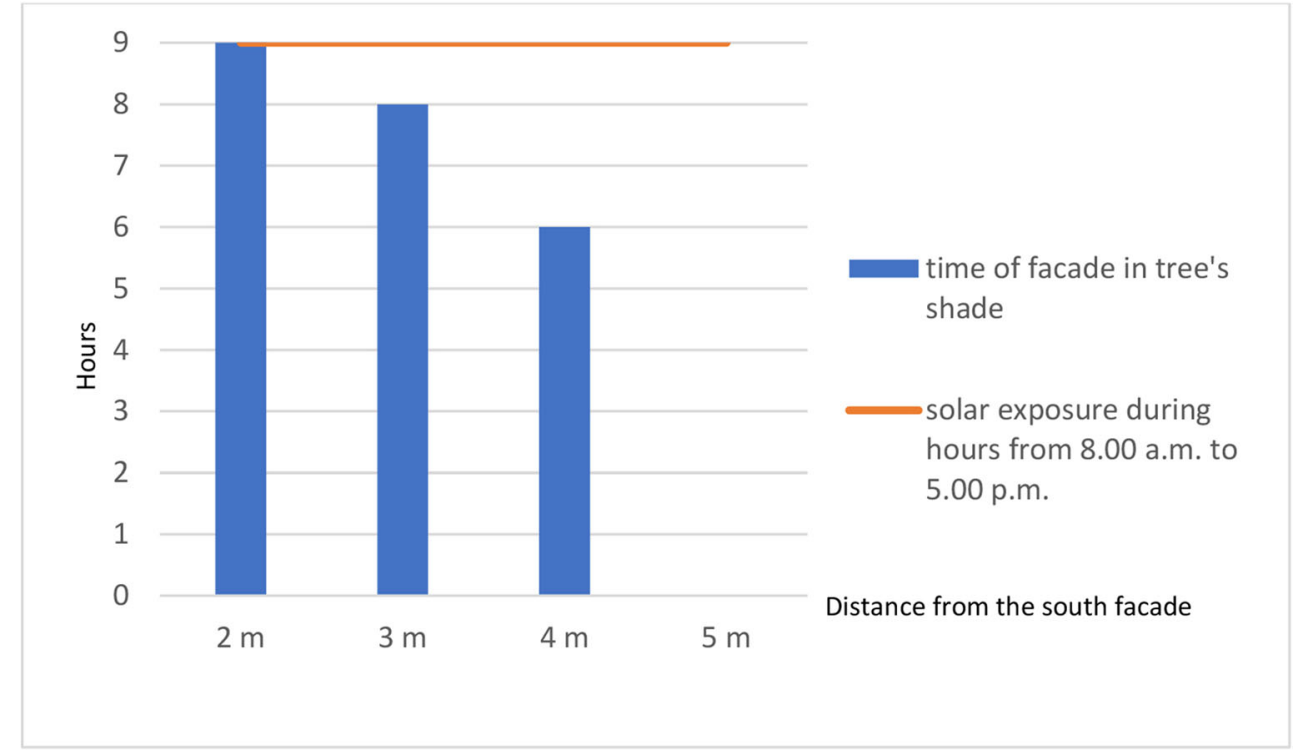


Fig. 7 Shading time for the southern facade by trees set at distances of 2,3,4 m away from the building developments, recorded between 8.00 a.m. to 5 p.m. (on July, 7th)

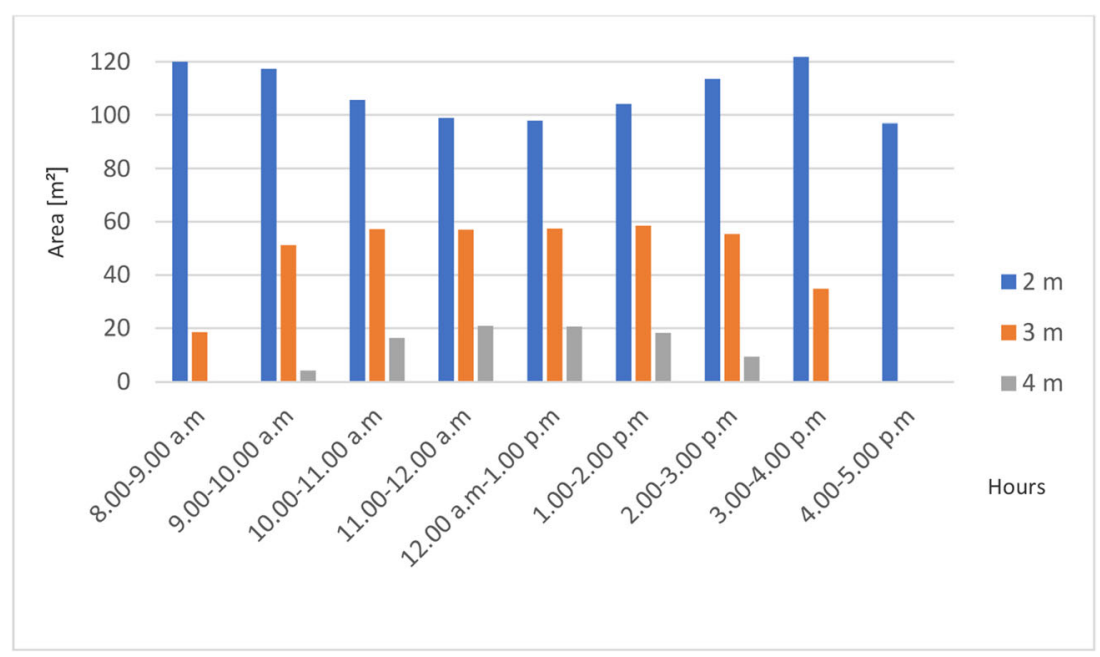

\section{Conclusion and discussion}

The simulation analysis conducted for the sake of the study proved that deciduous trees (20-25 year-old Sycamore Maple 'Rotterdam' trees) formed in a row, growing in a humid continental climate can provide solar protection measure for the south-oriented street frontage, mainly for part of its walls at the height of $6 \mathrm{~m}$ from the ground level. 7-m high greenery on a scale of an 18-m building can provide shade, first of all, for the ground floor and for the first floor level, provided the trees are located at an appropriate distance from the building developments they are to shade. As indicated by research results, if the trees are to act as shading elements in the street canyon located on the E-W axis, their location near walls exposed to insolation is recommended. It seems rational to keep the distance of $4 \mathrm{~m}$ as the maximum distance of trees from the southern facades (total shaded area of the ground floor façades equals $43.11 \%$ ). However, the location of high greenery within the range of 4 to $5 \mathrm{~m}$ away from buildings leads to a major reduction in the possibility of shading the wall surface by the plants (at 5-m distance it drops to $0 \%$ ). In turn, due to solar protection function, it seems most reasonable to maintain the distance of 2 to $3 \mathrm{~m}$ between the row of plants and building development they are to cover (over $90 \%$ of the ground floor facade is covered by sun protection measure). Nevertheless, such a close location can result in certain problems, due to fire regulations in force and due to possible damage caused by tree roots to underground parts of buildings. The development of the tree crown predicted for the selected plant species should also be taken into account, as, over time, a need to reshape it may arise due to its close proximity to the building. Differences in shading efficiency between row of trees located at the distance of 2 and $3 \mathrm{~m}$ are insignificant, thus the distance of $3 \mathrm{~m}$ seems more rational, as it makes it possible to minimize the risk of the problems mentioned. It also allows to arrive at a more beneficial pavement layout between the buildings and the row of trees. Moreover, for plantings close to the buildings, species or varieties with narrower habit can be chosen or rows with formed crowns, e.g., pleached trees.

Leafless trees may also provide a significant shade against insolation (Heisler 1977), as their presence is likely to reduce solar gains during the heating season (Mayer and Ali-Toudert 2005). In order to investigate the effectiveness of high greenery in terms of its impact on electricity consumption for the case under consideration further research need to be conducted. It would also be advisable to conduct simulations for more aged trees in order to examine their shading potential in the urban layout discussed in the study.

Despite certain unavoidable geometrical simplifications in the terms of the tree model adopted for research, the analyses described above makes it possible to illustrate the potential and scale of façade shading with the use of a row of trees, depending on the spatial relationship between the plants and the building developments located in a given street canyon. It has been demonstrated that, given proper location of the tree row, it is possible to provide effective solar protection to the glazing at the ground floor level, eliminating the need for additional shading systems (e.g. Venetian blinds, blinds, awnings). It has also been shown that geometric relationships between shading trees and buildings are constitute an extremely important parameter in providing solar protection. Appropriate location of high greenery not only affects the façade shading surface, but also influences the time and hours in which protection against direct solar radiation appears. This is crucial, among other aims, for the consumption of electricity required by room air conditioning systems (Donovan and Butry 2009). The analyses presented above are of practical value, whereas their development can lead to the formulation of recommendations that may prove useful for architects and landscape architects, with regard to the likelihood of benefiting from the shading function of trees. 
Authors' contribution Conceptualization, K.Zielonko-Jung and J.Janiak; methodology, K.Zielonko-Jung and J.Janiak; software, J.Janiak; validation, K.Zielonko-Jung and J.Janiak; formal analysis, K.Zielonko-Jung and J. Janiak; investigation, J.Janiak; resources, J.Janiak; data curation, J.Janiak; writing - original draft preparation, K.Zielonko-Jung and J.Janiak; writing - review and editing K.Zielonko-Jung and J.Janiak; visualization, J.Janiak, supervision K.Zielonko-Jung.

\section{Declarations}

Ethic approval and consent to participate Not applicable to this study.

Consent for publication The authors gives Urban Ecosystems consent for publication.

Competing interests There are no competing interests.

Financial interest The authors have no relevant financial or nonfinancial interests to disclose.

Open Access This article is licensed under a Creative Commons Attribution 4.0 International License, which permits use, sharing, adaptation, distribution and reproduction in any medium or format, as long as you give appropriate credit to the original author(s) and the source, provide a link to the Creative Commons licence, and indicate if changes were made. The images or other third party material in this article are included in the article's Creative Commons licence, unless indicated otherwise in a credit line to the material. If material is not included in the article's Creative Commons licence and your intended use is not permitted by statutory regulation or exceeds the permitted use, you will need to obtain permission directly from the copyright holder. To view a copy of this licence, visit http://creativecommons.org/licenses/by/4.0/.

\section{References}

Abdel-Aziz DM (2014) Effects of tree shading on building's energy consumption. Architectural Engineering Technology 3(4):1-7. https://doi.org/10.4172/2168-9717.1000135

Akbari H, Bretz SE, Kurn DM, Hanford J (1997) Peak power and cooling energy savings of shade trees. Energy Build 25(2):139-148. https:// doi.org/10.1016/S0378-7788(96)01003-1

Arnfield AJ (1990) Street design and urban canyon solar access. Energy Build 14(2):117-131. https://doi.org/10.1016/0378-7788(90) 90031-D

Błażejczyk K, Baranowski J, Błażejczyk A (2015) Forecast of changes in climate conditions in Poland up to 2100 year. In: J Puskarz \& D Przymanowska-Boniuk (Eds.), Climate Impact for Health in Poland: Current State and Forecast Until 2100 (pp.93-304). Wydawnictwo Akademickie SEDNO Spółka z o.o.: Warsaw, Poland, (in Polish)

Borowski J, Pstragowska M (2009) The basic directions of shaping trees. In: Drozdek ME, Wojewoda I, Purcel A (eds) Techniques and technologies for green areas, urban and rural greenery- contemporary and historic. Oficyna Wydawnicza Państwowej Wyższej Szkoły Zawodowej w Sulechowie, Sulechów, pp 7-18 (in Polish)

Bowler DE, Buyung-Ali L, Knight TM, Pullin AS (2010) Urban greening to cool towns and cities: a systematic review of the empirical evidence. Landsc Urban Plan 97(3):147-155. https://doi.org/10. 1016/j.landurbplan.2010.05.006

Czerwieniec M, Lewińska J (2000) Aesthetic functions. Social, didactic, educational and economic functions of green areas. In: Witkowska J (ed) Greenery in the city. Institute of Spatial and Communal Economy, Cracow, pp 45-49 (in Polish)

Donovan GH, Butry DT (2009) The value of shade: estimating the effect of urban trees on summertime electricity use. Energy and Build 41(6):662-668. https://doi.org/10.1016/j.enbuild.2009.01.002

Heisler G (1977) Trees modify metropolitan climate and noise. Arboric Urban For 3(11), 201-207. Available at: joa.isaarbor.com/articles. asp? JournalID=1\&VolumeID=3\&IssueID=11 (accessed on 06.03 . 2018)

Heisler G (1986) Effects of individual trees on the solar radiation climate of small buildings. Urban Ecol 9(3-4):337-359. https://doi.org/10. 1016/0304-4009(86)90008-2

Hes D, Dawkins A, Jensen C, Aye L (2011) A modelling method to assess the effect of tree shading for building performance simulation. Paper presented at the $12^{\text {th }}$ Conference of International Building Performance Simulation Association, Sydney, Commonwealth of Australia, 14-16 November, pp. 161-168. Available at: www. researchgate.net/publication/266483793 A modelling method to_assess_the_effect_of_tree_shading_for_building_performance simulation (accessed 19.02.2019)

Huang Q, Yang M, Hao AJ, Shuhua L, Bauer N (2020) Trees, grass, or concrete? The effects of different types of environments on stress reduction. Landsc Urban Plan 193:103654. https://doi.org/10.1016/ j.landurbplan.2019.103654

Klony,Wyszukiwarka Klonow (2019) Available online: http://www. klony.info/klony/klon/46 (accessed on 2 August 2019)

Kong L, Ka-Lun Lau K, Yuan C, Chen Y, Xu Y, Ren C, Ng E (2017) Regulation of outdoor thermal comfort by trees in Hong Kong. Sustain Cities and Soc 31:12-25.

Mayer H, Ali-Toudert F (2005) Thermal comfort in urban street with trees under hot summer conditions. Paper presented at the $22^{\text {nd }}$ Conference on Passive and Low Energy Architecture (PLEA), Beirut, Lebanon, 13-16 November. Available at: researchgate.net/ publication/261135276_Thermal_comfort in urban_streets_with trees under hot summer conditions (accessed on $05 \overline{5}$ March 2019)

McPherson EG, Heisler G (1988) Impacts of vegetation on residential heating and cooling. Energy and Build 12(1):41-51. https://doi.org/ 10.1016/0378-7788(88)90054-0

McPherson EG, Simpson JR (2003) Potential energy savings in buildings by an urban tree planting programme in California. Urban For Urban Green 2(2):73-86. https://doi.org/10.1078/1618-8667-00025

Navarrete-Hernandez P, Laffan K (2019) A greener urban environment: designing green infrastructure interventions to promote citizens' subjective wellbeing. Landsc Urban Plan 191:103618. https://doi. org/10.1016/j.landurbplan.2019.103618

Oke TR (1988) Street design and urban canopy layer climate. Energy and Build 11(1-3):103-113. https://doi.org/10.1016/0378-7788(88) 90026-6

Online maple catalog (2019) www.klony.info. (accessed on 2 August 2019)

Online plant catalog (2010) Acer pseudoplatanus Available online: http:// www.e-katalogroslin.pl/plants/235,klon-jawor_acerpseudoplatanus/ (accessed on 2 August 2019)

Seneta W, Dolatowski J (2012) Aceraceae. In: Dendrology, 4th edn. Publishing Company PWN SA, Warsaw, Poland, pp 352-372

Shashua-Bar L, Hoffman ME (2000) Vegetation as a climatic component in the design of an urban street an empirical model for predicting the 
cooling effect of urban green areas with trees. Energy and Build 31(3):221-235. https://doi.org/10.1016/S0378-7788(99)00018-3

Shashua-Bar L, Potcher O, Bitan A, Boltansky D, Yaakov Y (2009)

Microclimate modelling of street species effects within the varied urban morphology in the Mediterranean city of Tel Aviv, Israel. Int J Climatol 30:44-57. https://doi.org/10.1002/joc.1869

Simá E, Chagolla-Aranda MA, Huelsz G, Tovar R, Alvarez G (2015) Tree and neighbouring buildings shading effects on the thermal performance of a house in a warm sub-humid climate. Build Simul 8:711-723

Thayer RL, Maeda Jr, Maeda BT (1985) Measuring street tree impact on solar performance: a five-climate computer modelling study. Arboric Urban For 11(1), 1-12. Available at: joa.isa-arbor.com/ articles.asp?JournalID=1\&VolumeID=11\&IssueID=1 (accessed 19.02.2019) 